\title{
Major Salivary Gland Cancer pN1 TNM Finding v6 and v7
}

National Cancer Institute

\section{Source}

National Cancer Institute. Major Salivary Gland Cancer pN1 TNM Finding v6 and v7. NCI

Thesaurus. Code C65088.

Major salivary gland cancer with metastasis in a single ipsilateral lymph node, $3 \mathrm{~cm}$ or less

in greatest dimension. (from AJCC 6th and 7th Eds.) 